\title{
DETERMINATION OF GROWTH KINETICS AND BIOCHEMICAL COMPOSITION OF Nitzschia palea (Kützing) W. Smith ISOLATED FROM FRESHWATER SOURCES IN TURKEY
}

\author{
Dilek YALÇIN DUYGU
}

Gazi University, Faculty of Education, Department Secondary School Science and Mathematics Education, Division of Biology Education, Ankara, TURKEY

ORCID ID: orcid.org/0000-0003-2127-8186, e-mail: dilekduygu06@hotmail.com

\section{Cite this article as:}

Yalçın Duygu D. 2019. Determination of Growth Kinetics and Biochemical Composition of Nitzschia palea (Kützing) W.Smith Isolated from Freshwater Sources in Turkey. Trakya Univ J Nat Sci, 20(1): 63-70, DOI: 10.23902/trkjnat.498426

\begin{abstract}
This study was performed in order to bring out a detailed information on growth dynamics and biochemical determination of the diatom species Nitzschia palea (Kützing) W. Smith under batch culture conditions in order to pave the way for further studies. The study material was isolated from a fresh water sample collected from Ankara, Turkey. The diatoms were cultured in Allen medium for 168 hours and the growth dynamics were determined by cell density and dry weight analyses. Specific growth rate, duplication time of the culture and biochemical compositions were also investigated. Molecular characterization of the $N$. palea strain was performed by applying Fourier Transform Infrared Spectroscopy. The cell density and the dry biomass of the culture at the end of the 168 hours incubation period was determined as $2.0 \times 10^{6} \pm 1.0 \times 10^{5} \mathrm{cells} / \mathrm{mL}$ and $0.212 \pm 0.041 \mathrm{~g} \mathrm{~L}^{-1}$, respectively. The algal specific growth rate was found as $0.010 \mathrm{~h}^{-1}$ at $96-\mathrm{h}$ and the doubling time was calculated as $68 \mathrm{~h}^{-1}$. The protein content was measured as $41.21 \%$, carbohydrate content as $21.74 \%$, lipid content as $16.84 \%$ and ash content as $19.88 \%$. These results indicated that $N$. palea may be used in different fields of industries, especially in biodiesel production.
\end{abstract}

Key words: Nitzschia palea, batch culture, lipid, carbohydrate, protein, ash, FTIR.

Özet: Bu çalışma, daha ileri çalışmaların önünü açmak amacıyla yığın kültür koşullarında, Nitzschia palea (Kützing) W. Smith diatom türünün biyokimyasal tayini ve büyüme dinamikleri hakkında ayrıntılı bilgi vermek amacıyla yapılmıştır. Çalışma materyali, Ankara, Türkiye'den toplanan tatlı su örneğinden izole edilmiştir. Diatom kültürü Allen besi ortamında 168 saat boyunca yetiştirilmiş ve büyüme dinamikleri hücre yoğunluğu ile kuru ağırlık analizleriyle belirlenmiştir. Spesifik büyüme hızı, kültürün ikilenme süresi ve biyokimyasal bileşimleri de incelenmiştir. Nitzschia palea'nın moleküler karakterizasyonu Fourier Transform Infrared Spektroskopisi kullanılarak gerçekleştirilmiştir. Ekimi takip eden 168. saatte, Allen besi kültür ortamında kültürlerin hücre yoğunluğu 2,0x10 $\pm 1,0 \times 10^{5}$ hücre/mL ve kuru biyokütlesi $0,212 \pm 0,041\left(\mathrm{~g} \mathrm{~L}^{-1}\right)$ olarak tespit edilmiştir. Nitzschia palea'nın spesifik büyüme oranı 96 . saatte $\left(0,010 \mathrm{~h}^{-1}\right)$ ve ikilenme süresi $68 \mathrm{~h}^{-1}$ olarak hesaplanmışıtır. Nitzschia palea'nın protein miktarı (\%41,21), karbonhidrat miktarı $(\% 21,74)$, lipit miktarı $(\% 16,84)$ ve kül miktarı $(\% 19,88)$ olarak belirlenmiştir. Bu sonuçlar, N. palea'nın farklı endüstri alanlarında özellikle biyodizel üretimi için kullanılabileceğini göstermiştir.

\section{Introduction}

Diatoms are single-celled, microscopic and photosynthetic algae. They are the most prominent oxygen synthesizers and play a key role by being one of the most important biomass sources in oceans (Bozarth et al. 2009). Every diatom is placed in a fine (nano-scale) micro shell, and thus is the most substantial organisms among microalgae (Belegratis et al. 2014). A distinctive feature of diatoms is that they have a frustule composed of hydrated silicon dioxide and organic materials. Although diatoms have mainly been the field of interest academic studies, they are currently been utilized in a wide range of other fields. Recently, diatoms have been used frequently in nanotechnology due to their nanomolecular biosilica shells. The applications of different

materials and technologies inspired by diatoms are common and include multiple disciplines (Van den Hoek et al. 1995), including environmental indicators of aquatic systems, bioremediators of contaminated water, pharmaceuticals, molecular sieves, materials relevant to nanotechnology, sensors, filters, health foods, resins, biomolecules, isolators, electronics and optical coatings (Bozart et al. 2009, Lakshmi et al. 2014). Diatoms are also defined as an appropriate alternative for the biodiesel production because they can be easily converted into biodiesel by transesterification reaction of triacylglycerols (TAG), which make up $60 \%$ of their cells. Nitzschia is a freshwater diatom which is was determined to have high lipid production (Yu et al. 2009). Therefore, 
in recent years, most of the studies on Nitzschia species focused on increasing the intracellular lipid content and related biodiesel production. Vitug \& Baldia (2014) cultivated Nitzschia palea (Kützing) W. Smith under various culture conditions and reported that the diatoms increased their lipid contents with changing light intensity, $\mathrm{pH}$ and temperature conditions. Nitzschia palea was grown in different culture media with different nutrients and tested as a model diatom to reveal its suitability as biodiesel raw material. The results of these and similar studies revealed that more intensive and comprehensive studies are needed for production of biodiesel from $N$. palea (Abdel-Hamid et al. 2013). In recent years, researchers have investigated the ability of Bacillariophyceae members to produce biologically active compounds and they have reported that they might be appropriate for antibiotic production. For instance, Binea et al. (2009) tested the extracts obtained from $N$. palea on some pathogenic bacteria and reported that the extracts were effective on some gram-positive bacteria. However, some of the features of diatom metabolism and the production of natural compounds are still unknown.

Fourier Transform Infrared (FTIR) Spectroscopy has been a widely used method through its wavenumbers causing vibrations on the functional constituents in molecules. Concerning algae, infrared microscopy enables spatial resolution and allows the analysis of macromolecules (Murdock \& Wetzel 2009). Algal infrared microscopy research has focused on several macromolecular pools, including proteins (amide I and II), lipids (methyl and methylene groups, esters), carbohydrates (starch, cellulose), nucleic acids and phosphorous groups, and silica (in diatoms). FTIR spectroscopy is also applied for taxonomic purposes for species differentiation and classification (Vardy \& Uwins 2002, Dean et al. 2010).

Despite the potential role of diatoms in all these issues mention above, it is obvious that specific studies on the biomass, growth and biochemical composition of diatom species are needed in this field. The present study was carried as a pilot study of a project aiming to increase the intracellular lipid content in N. palea. More specifically, this study was performed to determine the effects of culture media and conditions on biomass and growth rates of $N$. palea and to determine biochemical composition and application of FTIR spectroscopy for molecular characterization of the species.

\section{Materials and Methods}

\section{Isolation and culture conditions}

The diatom species $N$. palea was isolated from a freshwater source (Bilkent University well) in Ankara, Turkey. The fresh water sample was brought to the laboratory and was transferred to the liquid nutrient medium prepared for pre-enrichment of cultures. The liquid nutrient medium consisted of $\mathrm{MgSO}_{4} \cdot 7 \mathrm{H}_{2} \mathrm{O}(2.50$ g), $\mathrm{KNO}_{3}(5.0 \mathrm{~g}), \mathrm{KH}_{2} \mathrm{PO}_{4}(1.25 \mathrm{~g}), \mathrm{FeSO}_{4} \cdot 7 \mathrm{H}_{2} \mathrm{O}(0.009$ $\mathrm{g})$, and distilled water $(1000 \mathrm{~mL})$. The micromanipulation technique was used for isolation of the diatoms. The examined cells were removed by means of a micropipette, dropped on a sterile agar plate and then transferred to culture tubes. The culture tubes were placed under appropriate low temperature conditions $\left(19-20^{\circ} \mathrm{C}\right)$. Control of the growth was performed by microscopic investigations approximately 2-3 weeks after the transfer of cultures to the medium (Perumal et al. 2012). The isolated diatoms were inoculated into fresh medium, and were identified by using identification keys (Krammer \& Lange-Bertalot 1999).

The Allen medium was used for growth of $N$. palea cultures. The medium contained $\mathrm{NaNO}_{3}(1.5 \mathrm{~g} / \mathrm{L})$, P-IV Metal Solution $(1 \mathrm{~mL} / \mathrm{L}):\left[\mathrm{K}_{2} \mathrm{HPO}_{4}(5 \mathrm{~mL} / \mathrm{L})(1.5 \mathrm{~g} / 200\right.$ $\left.\left.\mathrm{mL} \mathrm{dH}_{2} \mathrm{O}\right)\right],\left[\mathrm{MgSO}_{4} \cdot 7 \mathrm{H}_{2} \mathrm{O}(5 \mathrm{~mL} / \mathrm{L})(1.5 \mathrm{~g} / 200 \mathrm{~mL}\right.$ $\left.\left.\mathrm{dH}_{2} \mathrm{O}\right)\right],\left[\mathrm{Na}_{2} \mathrm{CO}_{3}(5 \mathrm{~mL} / \mathrm{L})\left(0.8 \mathrm{~g} / 200 \mathrm{~mL} \quad \mathrm{dH}_{2} \mathrm{O}\right)\right]$, $\left[\begin{array}{llllll}\mathrm{CaCl}_{2} \cdot 2 \mathrm{H}_{2} \mathrm{O} & (10 \mathrm{~mL} / \mathrm{L}) & (0.5 & \mathrm{g} / 200 & \mathrm{~mL} & \left.\mathrm{dH}_{2} \mathrm{O}\right)\end{array}\right]$, $\left[\mathrm{Na}_{2} \mathrm{SiO}_{3} \cdot 9 \mathrm{H}_{2} \mathrm{O}(10 \mathrm{~mL} / \mathrm{L})\left(1.16 \mathrm{~g} / 200 \mathrm{~mL} \mathrm{dH} \mathrm{H}_{2} \mathrm{O}\right)\right.$, [Citric

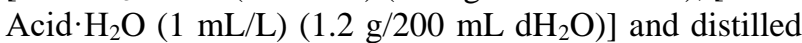
water was added to $1000 \mathrm{~mL}$ of final volume (UTEX 2018).

The ambient temperature of the laboratory where the experiments were conducted was kept at $23 \pm 3{ }^{\circ} \mathrm{C}$. The illumination of the laboratory was provided by a cool daylight lamp (Philips, $50 \mu \mathrm{mol}$ photons $\mathrm{m}^{-2} \mathrm{~s}^{-1}$ ) at a horizontal distance of $22 \mathrm{~cm}$ from the cultures. Cultures were exposed to the light in a 16:8 light:dark regime. The $\mathrm{pH}$ of nutrient media was adjusted to 6.5-7. In the experiments, $250 \mathrm{~mL}$ nutrient media and $50 \mathrm{~mL}$ suspended culture were inoculated. Sterilized air was provided using a disposable syringe filter. Culture flasks were placed in a shaker (Stuart SSL1 Shakers) and the speed of the shaker was adjusted to $120 \mathrm{rpm}$. All tests were carried out in triplicate.

\section{Fourier Transform Infrared (FTIR) Spectrometry}

Morphology and surface structures of the diatoms were characterized by applying FTIR. Infrared analysis was carried out at Bilkent University Institute of Materials Science and Nanotechnology, Ankara, Turkey, using a Vertex 70 with a Hyperion microscope fitted with a Bruker Tensor 37 FTIR spectrometer. FTIR measurements were done in the range of 800 and $4000 \mathrm{~cm}^{-}$ 1 , with $4 \mathrm{~cm}^{-1}$ resolution and a $20 \times 20 \mu \mathrm{m}$ square aperture. 128 scans were taken for 1 spectrum (Duygu et al. 2012).

\section{Analytical methods}

Cell density (cells/mL) was determined by counting 16 medium squares in a Thoma counting slide. Cell counts were performed under a light microscope at $400 \mathrm{X}$ magnification. Diatom frustules devoid of chloroplasts were not included in the counts. After the diatom sample was homogenized, it was applied into the counting chamber using a Pasteur pipette. The cells were homogenously distributed to the entire chamber area and the counting process was started. The counting was repeated four times and the mean number of cells in $\mathrm{mL}$ was calculated (Cirik \& Gökpınar 1993). The cell counts were carried out at the beginning of the showing 
procedure at ranges of $(0,24,48,72,96,120,144$ and 168) hours. The formula $\mathrm{N} x 10,000$ (cells $/ \mathrm{mL}$ ), where $\mathrm{N}=16$ is the number of cells counted in the medium square, 10,000 is the invariant which is used to obtain a standard result and to convert the counting result from 0.1 $\mathrm{mm}^{3}$ to $1 \mathrm{~mL}$, was used for countings (Gürgün \& Halkman 1990).

The specific growth rate $(\mu)$ was defined as the increase in cell density and formulated. Specific growth rate and duplication time were calculated using Eq. 1 and Eq. 2, respectively (Wong et al. 2017).

$$
\begin{array}{ll}
\mu=\frac{\ln \left(\frac{\mathrm{x} 1}{\mathrm{X} 0}\right)}{t 1-t 0} & \text { (1) }(\mu: \text { Specific growth rate; } \mathrm{x} 0 \text { and } \mathrm{x} 1 \\
=\text { Biomass concentration at } t 0 \text { and } t 1) \\
D T=\frac{\ln 2}{\mu} & \text { (2) (DT: Duplication time) }
\end{array}
$$

Determination of yields of $N$. palea cultures was carried out by measuring the weights at the $168^{\text {th }}$ hour of cultivation of the cultures. During the exponential growth phase, approximately $10 \mathrm{~mL}$ aliquot of the culture was taken to determine the dry weight. Algal sample was centrifuged, the supernatant was discarded and washed with $20 \mathrm{~mL}$ of distilled water. The samples were filtered through vacuum filtration with glass-fiber filters (Whattman, GF/C), as pre-dried and weighed. The filters were dried at $105^{\circ} \mathrm{C}$ for 24 hours, the dry weight was determined and finally weighed with a digital balance. Biomass was determined by the difference in weights (Fimbres-Olivarría et al. 2015).

\section{Biochemical analyses}

Nitzschia palea samples $(300 \mathrm{ml})$ were centrifuged with a high-speed centrifuge (Rotor R10A5) at 10,000 rpm and $4{ }^{\circ} \mathrm{C}$. Approximately $5 \mathrm{ml}$ samples were transferred to Falcon tubes and lyophilized for 48 hours at $-85{ }^{\circ} \mathrm{C}$ and 0.002 mbar vacuum. Freeze-dried samples were used for nutrient analysis. Nutrients (crude protein, total lipid, and total carbohydrate), dry matter and ash of the samples were determined according to the AOAC (1990). Nutrient analysis was carried out at Ankara University Faculty of Veterinary Medicine, Ankara, Turkey.
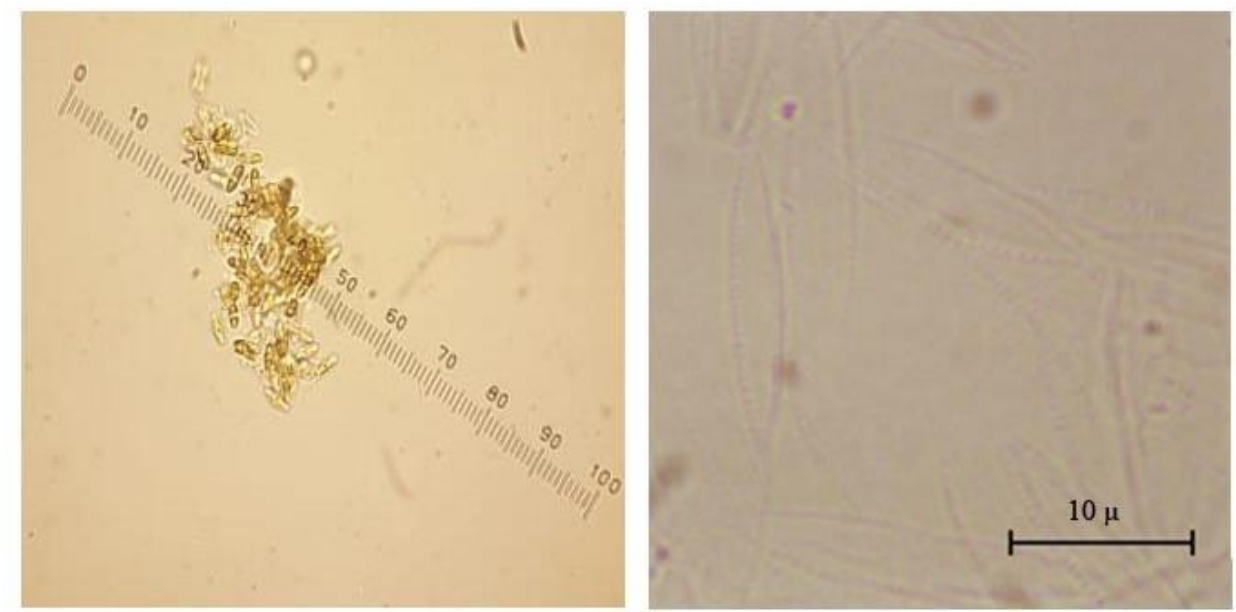

Fig. 1. Microscopic images of $N$. palea (400X right and 1000X left)

\section{$\underline{\text { Statistical Analysis }}$}

The minimum, maximum, mean and standard deviation values of quantitative measurements were obtained using the statistical analysis option of Microsoft Excel.

\section{Results}

The diatoms used in the study were isolated from the samples collected from the freshwater source described above, and they were identified as $N$. palea. The microscopic measurements revealed that the cell weight ranged from 2.5 to $3 \mu \mathrm{m}$ and the cell length from 15 to 30 $\mu \mathrm{m}$. In addition, the presence of 28-30 stria at $10 \mu \mathrm{m}$ was determined. The taxonomic classification of $N$. palea and its appearance under the light microscope are shown in Fig. 1 (Krammer \& Lange-Bertalot 1999; Guiry \& Guiry 2018).

The first cell counts of the inoculations in the nutrient medium were in the range of $8.70 \times 10^{5}-8.71 \times 10^{5}$ cells $/ \mathrm{mL}$. The total increase of cell density in the medium throughout the 168-h study period is given in Table 1 . The cell density at the end of the culture period was determined as $2.0 \times 10^{6} \pm 1.0 \times 10^{5}$ cells $/ \mathrm{mL}$ (Fig. 2). Dry biomass of the cultures was measured at 168 -h and found as $0.212 \pm 0.041\left(\mathrm{~g} \mathrm{~L}^{-1}\right)$ (Table 1$)$. The algal growth rate was found at $96-\mathrm{h}\left(0.010 \mathrm{~h}^{-1}\right)$, and doubling time was calculated as $68 \mathrm{~h}^{-1}$ (Table 1 and Fig. 2).

The biochemical composition of $N$. palea was performed by applying standard methods and the results have been shown in Table 2 .

The absorption spectra of the culture had 9 clear bands over the wavenumber range of 800 to $4000 \mathrm{~cm}^{-1}$ (Fig. 3). Each peak was assigned a functional group (Table 3 ). The bands were tentatively identified on the basis of published data for phytoplankton, bacteria, on other biological materials and reference standards (Kumar et al. 2018). The peak at $1072 \mathrm{~cm}^{-1}$ corresponds to $\mathrm{Si}-\mathrm{O}$ bonding (Table 3). The other peaks have been considered as organic structural peaks. 
Table 1. Cell density, dry biomass weight, spesific growth rate (SGR $\mu$ ) and duplication time (DT) of N. palea.

\begin{tabular}{|c|c|c|c|c|c|c|c|}
\hline \multicolumn{2}{|c|}{$\begin{array}{l}\text { Cell Density (0h) } \\
(\text { Cells/mL) }\end{array}$} & \multicolumn{2}{|c|}{$\begin{array}{l}\text { Cell Density (168h) } \\
(\text { Cells/mL) }\end{array}$} & \multicolumn{2}{|c|}{$\begin{array}{c}\text { Dry Biomass } \\
\left(\mathrm{g} \mathrm{L}^{-1}\right)\end{array}$} & \multirow{2}{*}{$\begin{array}{c}\begin{array}{c}\text { SGR } \\
(\mu)\end{array} \\
\left(h^{-1}\right)\end{array}$} & \multirow{2}{*}{$\begin{array}{c}\text { DT } \\
\left(\mathbf{h}^{-1}\right)\end{array}$} \\
\hline Min.; Max. & Avr. \pm SD & Min.; Max. & Avr. \pm SD & Min.; Max. & Avr. \pm SD & & \\
\hline $8.70 \times 10^{5} ; 8.71 \times 10^{5}$ & $8.71 \times 10^{5} \pm 5.51 \times 10^{3}$ & $1.9 \times 10^{6} ; 2.0 \times 10^{6}$ & $2.0 \times 10^{6} \pm 1.0 \times 10^{5}$ & $0.171 ; 0.253$ & $0.212 \pm 0.041$ & 0.010 & 68 \\
\hline
\end{tabular}
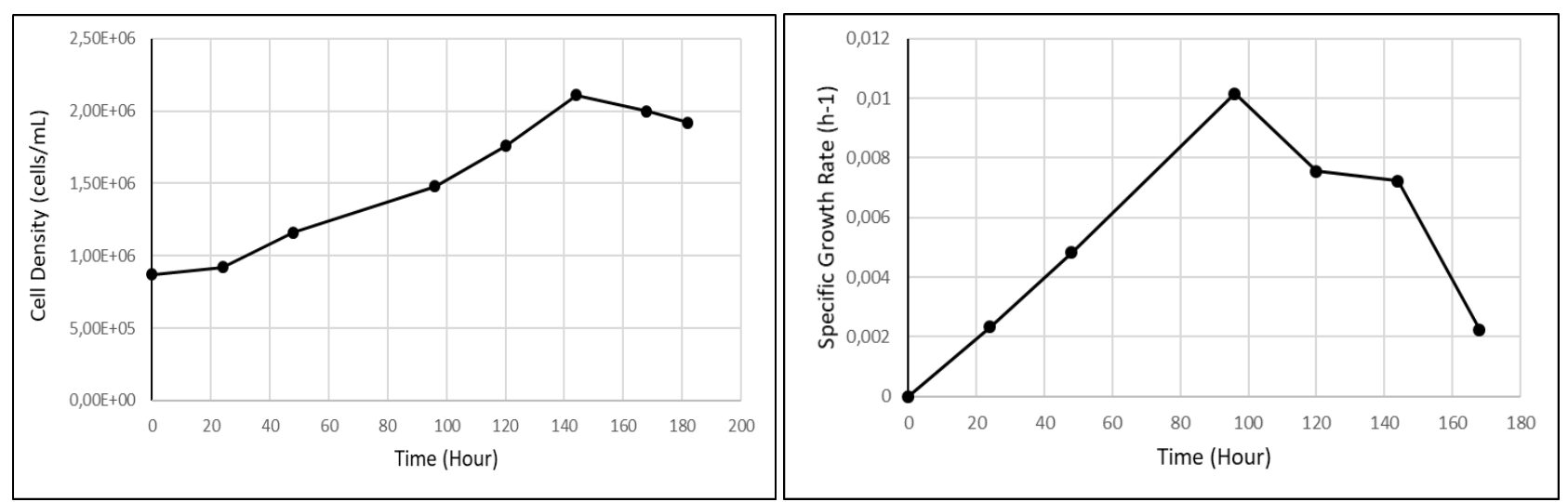

Fig. 2. Cell density and specific growth rate of N. palea.

Table 2. Total protein, carbohydrate, lipid and ash contents of N. palea.

\begin{tabular}{cccc}
\hline \hline Protein (\%) & Carbohydrate (\%) & Lipid (\%) & Ash (\%) \\
\hline \hline $41.21 \pm 0.11$ & $21.74 \pm 0.10$ & $16.84 \pm 0.32$ & $19.88 \pm 0.07$ \\
\hline \hline
\end{tabular}

Data are given as mean \pm standard deviation of triplicates. Mean values were given, $\mathrm{n}=3$.

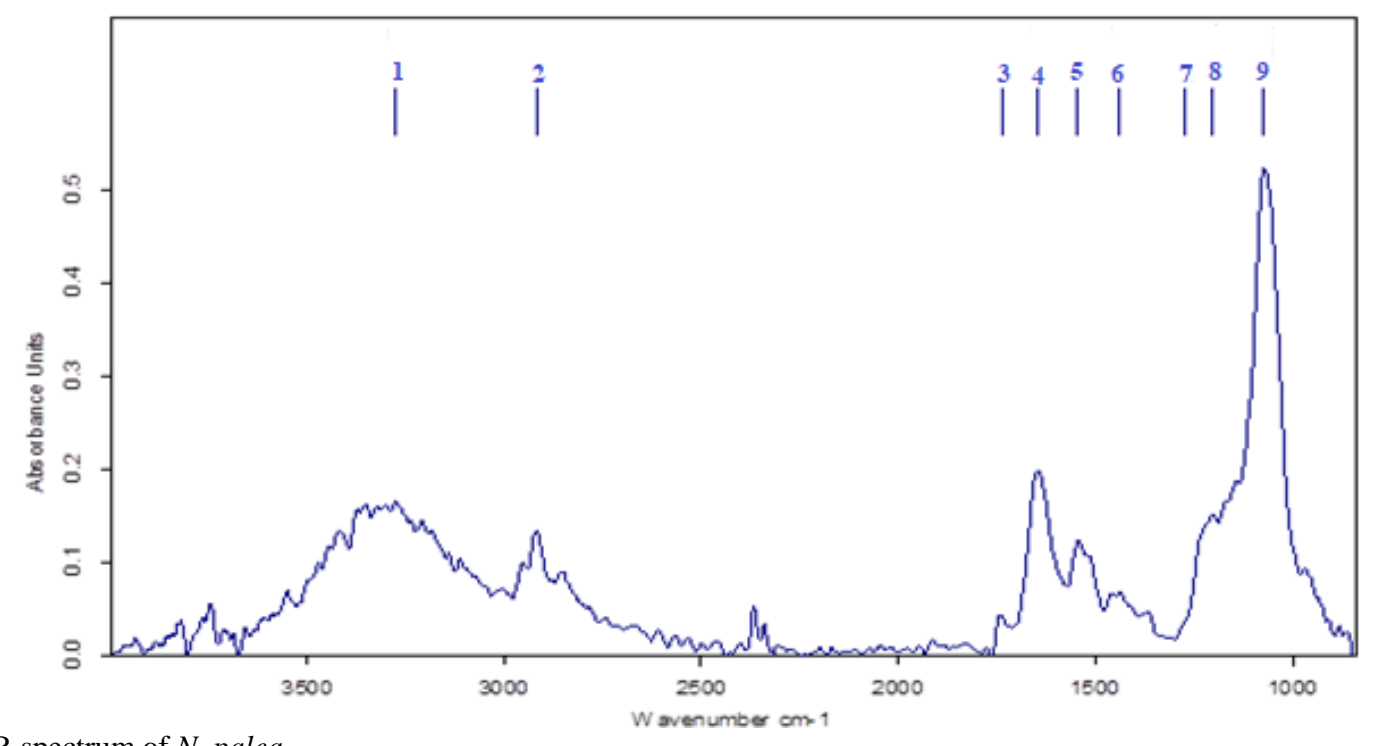

Fig. 3. FTIR spectrum of N. palea.

\section{Discussion}

Biomass and biochemical composition are critical parameters in selecting microalgal species for scale-up production. Adaptation and tolerance to environmental change is another significant factor to consider for cultivation and biomass production (Dębowski et al. 2012). In this study, N. palea, which was collected and isolated from its natural environment, was tried to be produced by providing optimum conditions in the laboratory. The culture conditions have sufficiently supported the growth of $N$. palea and this result is an important development in terms of biomass productivity.

The process of making microalgae cultures under laboratory conditions is based on the method in which a relatively small number of cells are inoculated and then exposed to appropriate light, temperature and ventilation conditions. The increase in the number of cells in such a culture follows a characteristic path in which different 
Table 3. Tentative assignment of bands found in the FTIR spectra of N. palea ${ }^{1}$

\begin{tabular}{|c|c|c|c|}
\hline $\begin{array}{l}\text { Band } \\
\text { No }\end{array}$ & $\begin{array}{c}\text { Band } \\
\text { Wavenumber } \\
\left(\mathbf{c m}^{-1}\right)\end{array}$ & Region in $\left(\mathrm{cm}^{-1}\right)$ & Tentative Assignment of Bands \\
\hline 1 & 3273 & $3029-3639$ & $\begin{array}{l}\text { Water } v(\mathrm{O}-\mathrm{H}) \text { stretching } \\
\text { Protein } v(\mathrm{~N}-\mathrm{H}) \text { stretching (amide A) }\end{array}$ \\
\hline 2 & 2915 & $2809-3012$ & $\begin{array}{l}\text { Lipid - Carbohydrate } \\
\text { Mainly } v_{\text {as }}\left(\mathrm{CH}_{2}\right) \text { and } v_{\mathrm{s}}\left(\mathrm{CH}_{2}\right) \text { stretching }\end{array}$ \\
\hline 3 & 1735 & $1763-1712$ & $\begin{array}{l}\text { Cellulose-Fatty Acids } \\
v(\mathrm{C}=\mathrm{O}) \text { stretching of esters }\end{array}$ \\
\hline 4 & 1643 & $1583-1709$ & Protein amide I band, mainly $v(\mathrm{C}=\mathrm{O})$ stretching \\
\hline 5 & 1516 & $1481-1585$ & Protein amide II band, mainly $\delta(\mathrm{N}-\mathrm{H})$ bending and $v(\mathrm{C}-\mathrm{N})$ stretching \\
\hline 6 & 1432 & $1425-1477$ & $\begin{array}{l}\text { Protein } \delta_{\text {as }}\left(\mathrm{CH}_{2}\right) \text { and } \delta_{\text {as }}\left(\mathrm{CH}_{3}\right) \text { bending of methyl } \\
\text { Lipid } \delta_{\text {as }}\left(\mathrm{CH}_{2}\right) \text { bending of methyl }\end{array}$ \\
\hline 7 & 1381 & $1357-1423$ & $\begin{array}{l}\text { Protein } \delta_{\mathrm{s}}\left(\mathrm{CH}_{2}\right) \text { and } \delta_{\mathrm{s}}\left(\mathrm{CH}_{3}\right) \text { bending of methyl } \\
\text { Carboxylic Acid } v_{\mathrm{s}}(\mathrm{C}-\mathrm{O}) \text { of } \mathrm{COO}^{-} \text {groups of carboxylates } \\
\text { Lipid } \delta_{\mathrm{s}}\left(\mathrm{N}\left(\mathrm{CH}_{3}\right)_{3}\right) \text { bending of methyl }\end{array}$ \\
\hline 8 & 1202 & $1191-1356$ & $\begin{array}{l}\text { Nucleic Acid (other phosphate-containing compounds) } v_{\mathrm{as}}(>\mathrm{P}=\mathrm{O}) \text {; stretching of } \\
\text { phosphodiesters }\end{array}$ \\
\hline 9 & 1072 & $\begin{array}{l}1060,1072 \\
1086\end{array}$ & $\begin{array}{l}\text { For silica several bands Si-O-Si stretching } \\
\text { Carbohydrate } \\
v(\mathrm{C}-\mathrm{O}-\mathrm{C}) \text { of polysaccharides } \\
\text { Nucleic Acid (and other phosphate-containing compounds) } v_{\mathrm{s}}(>\mathrm{P}=\mathrm{O}) \text { stretching } \\
\text { of phosphodiesters }\end{array}$ \\
\hline
\end{tabular}

growth phases can be recognized (Chaumont 1993, Perumal et al. 2012). There are four growth phases for microalgae cultures. Cells, which are taken from stock cultures and inoculated into a new culture medium should be able to accommodate adaptation. Therefore, there is no cell division for a few hours and this stage is known as the lag or induction phase. Cells, which are adapted to the new medium, start to grow and the culture reach a maximum concentration in 12-18 hours. This phase is known as the exponential phase. At this phase, cells are logarithmically increased in successive equal intervals of time. When the cells reach their maximum concentration, cell growth and reproductions are gradually decreased. This phase is known as the declining phase. In stationary phase cultures, net reproduction is zero and cells undergo biochemical changes within certain hours. In the death phase (crash phase), metabolism of vegetative cell has not been in a good condition for a long time and this phase takes place very quickly. Reduction of nutrients, oxygen deficiency, overheating, and $\mathrm{pH}$ changes fall into factors causing deterioration of the cultures (Michelle et al. 2005, Ammar 2016).

In this study, four growth phases were observed during the growth of N. palea in Allen medium (Fig. 2). Nitzschia palea culture reached its maximum growth rate at 96-h. This phase can be defined as the exponential phase of $N$. palea under present culture conditions. After this phase, cell growth and reproduction began to decline gradually.

Nitzschia palea cell density increased in the following hours after inoculation and the cell density was determined as $\left(2.0 \times 10^{6} \pm 1.0 \times 10^{5}\right.$ cells $\left./ \mathrm{mL}\right)$ at 168 -h. Rodríguez-Núñez \& Toledo-Agüero (2017) reported that the cell density of Nitzschia sp. was $1.3 \times 10^{7}$ (cells $/ \mathrm{mL}$ ), which was higher than our results. Supriya et al. (2012) found the cell number as $5.31 \times 10^{4}($ cells $/ \mathrm{mL})$ when Nitzschia sp. was cultured in different media. This value is lower than the $N$. palea cell density value obtained in the present study. The maximum growth rate was reached at $96-\mathrm{h}$. The maximum growth rate calculated as $0.010 \mathrm{~h}^{-}$ ${ }^{1}$ and the duplication time calculated as $68 \mathrm{~h}^{-1}$ are lower those found by (Rodríguez-Núñez \& Toledo-Agüero 2017) $\left(0.58 \mathrm{~d}^{-1}\right)$ and (Abdel-Hamid et al. 2013) (0.041 $\left.0.66 \mathrm{~d}^{-1}\right)$. In contrast, Supriya et al. (2012) determined the specific growth rate at $0.041 \mathrm{~h}^{-1}$, which is higher than in this study.

Biomass amount and production are other evaluation features used in the selection of microalgae for cultivation. In other words, microalgae must have a short life cycle that can be reproduced under controlled conditions. The total biomass production (dry weight) of $N$. palea was recorded as $0.212 \pm 0.041 \mathrm{~g} \mathrm{~L}^{-1}$ and reached its maximum value at $7^{\text {th }}$ day. Lourduraj \& Abraham (2016) found the dry weight of $N$. palea $(0.524 \pm 0.034 \mathrm{~g}$ $\left.\mathrm{L}^{-1}\right)$ in the biomass and lipid increase study. A similar study by Abdel-Hamid et al. (2013) found the dry weight of $N$. palea as $0.16-0.27 \mathrm{~g} \mathrm{~L}^{-1}$.

It has been considered that this change in the cell density and dry weight are observed due to the culture conditions, methods, different nutrient components in the media and the fact that the tested strains may be different.

In the production of biomass, the target microalgae should have appropriate nutritional contents. This content may depend on the microalgae culture and the phase in which the culture is harvested. In algal cultures, crude protein is produced as the primary organic component 
during the logarithmic growth phase. Since the depletion of the components in the medium is in the stationary phase, the biochemical content in the cell decreases during this phase (Rodríguez-Núñeza \& Toledo-Agüeroc 2017). Although this is more common in batch cultures, it can be removed by adding nutrients in continuous or semicontinuous cultures. In this study, biochemical analyses of $N$. palea was performed when the culture was in the exponential growth phase. In this study, the amount of protein was determined as $41.21 \%$, carbohydrate content as $21.74 \%$, lipid content as $16.84 \%$ and ash content as $19.88 \%$. In a study carried out on the fatty acid profile and nutritional composition of diatoms by Rodríguez-Núñez \& Toledo-Agüero (2017), the total lipid content was determined as $18.36 \%$, crude protein content as $43.16 \%$, carbohydrate content as $18.88 \%$ and ash content as $19.60 \%$, all in showing similaritiesto the findings of this study.

Recently, one of the areas where researchers had substantial interest was on obtaining lipid from microalgae. Microalgal lipids are used in two main fields: biofuels and food industry. Some microalgae produce large amounts of lipid in the form of triacylglycerides (TAGs). Microalgae synthesize very -long-chain polyunsaturated fatty acids (PUFA). Physical ( $\mathrm{pH}$, temperature, light) and chemical (nitrogen, carbon, phosphorus, iron, salt concentration) parameters affect the lipid composition of microalgae (Minhas et al. 2016). Many microalgae species show changes in their lipid contents in stress conditions. Examples of studies on the effect of stress factors on lipid and bioactive production include Chlorella vulgaris and Pseudokirchneriella subcapitata (Gonçalves et al. 2013), Haematococcus pluvialis (Imamoglu et al. 2009), Scenedesmus sp. (Rodolfi et al. 2009), Nitzschia laevis (Wen \& Chen 2001) and Arthrospira platensis (Markou et al. 2013). Lipids are secondary metabolite products of diatoms and play a role in responding to changes in the environment and maintain specific membrane functions ( $\mathrm{Hu}$ et al. 2008). In this study, total lipid amount was determined as $16.84 \%$. However, Lourduraj \& Abraham (2016) and AbdelHamid et al. (2013) determined total lipid amount as $40 \%$ and $20 \%$, respectively, which were higher than the lipid obtained in this study. However, these studies have pointed out that the amount of intracellular lipid can be increased in diatoms.

Diatoms can rapidly adapt to changing nutrient conditions in aquatic environments. Where the water rises and the nutrients are deposited on the surface, the diatoms are highly effective for the intake of nutrients such as iron, nitrogen and silicon that limit growth. Diatoms can use a variety of nitrogen sources containing inorganic $\left(\mathrm{NO}_{3}{ }^{-}\right.$, $\mathrm{NH}_{4}^{+}$) and organic (urea, amino acids) nitrogen. The type of the nitrogen source can affect microalgae growth and microalgae adapt the nitrogen metabolism according to the nutrients available (Li et al. 2014). Sodium nitrate is an appropriate nitrogen source for cell growth and lipid production of diatoms. When the nitrogen sources were compared, it has been found that sodium nitrate was superior to urea. Li et al. (2008) observed that sodium nitrate is the best source of nitrogen for Neochloris oleoabundane for both cell growth and lipid accumulation. Similarly, sodium nitrate in the composition of Allen medium was found to be effective in the growth of N. palea. Silicon is an important nutrient that affects cellular metabolism for diatoms. The silicon source of Allen medium used in this study is $\mathrm{Na}_{2} \mathrm{SiO}_{3} \cdot 9 \mathrm{H}_{2} \mathrm{O}$. There are a wide range of freshwater nutrient media used for the cultivation of diatoms. The most commonly used media are Chu No.10 medium (Nichols 1973), WC medium (Guillard \& Lorenzen 1972), DM (Diatom Medium) (CCAP 2018), f/2 Medium (Guillard \& Ryther 1962). Although Allen nutrient medium is frequently applied in the production of blue green-algae, it was shown that this medium is also effective in the growth of diatom $N$. palea.

Diatom species have different types and concentrations of organic contents, and FTIR spectra can give very reliable information about this content. The FTIR study of a bioactive surface such as microorganisms and microalgae reveal the presence of many functional groups on their surfaces (Kumar et al. 2018). FTIR spectroscopy is applied in order to detect specific functional groups that help determine the presence of some components (Fig. 3). The peak area and intensity observed in the FTIR spectra reveal the abundance of a particular functional group. FTIR spectra of the diatom surface showed strong peaks around $\sim 1049$ and $\sim 1070 \mathrm{~cm}^{-}$ 1. This is characteristic of the $\mathrm{Si}-\mathrm{O}$ bond, and the interaction of diatom surfaces with inorganic and organic materials leads to a change in the absorption band of Si$\mathrm{O}, \mathrm{Si}-\mathrm{OH}$ and Si-O-Si (Losic et al. 2009). The FTIR spectra of $N$. palea given in Table 3 indicated the position and nature of absorption bands. Nitzschia palea has a strong extensive absorption band at $3273 \mathrm{~cm}^{-1}$ in the $3029-3639 \mathrm{~cm}^{-1}$ range. This absorption band is hydroxyl $\mathrm{O}-\mathrm{H}$ stretching functional group. Nitzschia palea has a sharp band in the wavelength region of $2809-3012 \mathrm{~cm}^{-1}$. The absorption band at $2915 \mathrm{~cm}^{-1}$ shows the aliphatic functional group with the asymmetric stretching $\mathrm{CH}_{2}$ and the methyl C-H symmetric stretching/lipid (Swann \& Patwardhan 2011). The absorption bands of $1643 \mathrm{~cm}^{-1}$ (amide I) and $1516 \mathrm{~cm}^{-1}$ (amide II) were due primarily to $\mathrm{C}=\mathrm{O}$ stretching vibration and a combination of $\mathrm{N}-\mathrm{H}$ and $\mathrm{C}-\mathrm{N}$ stretching vibrations in amide complexes (Murdock \& Wetzel 2009). Lipid spectra were characterized by two sets of strong vibrations: $\mathrm{C}-\mathrm{H}$ at $2915 \mathrm{~cm}^{-1}$ and the $\mathrm{C}=\mathrm{O}$ mode of the side chain from the ester carbonyl group at $1735 \mathrm{~cm}^{-1}$. In the wave number range of $900-1300 \mathrm{~cm}^{-1}$, $N$. palea showed strong and broader absorption band $\left(1072 \mathrm{~cm}^{-1}\right)$. These bands showed the presence of polysaccharides ( $\mathrm{C}-\mathrm{O}$ str) and for silica several bands ( $\mathrm{Si}$ O-Si str).

\section{Conclusion}

In this study, $N$. palea isolated from fresh water resource was examined under culture conditions. The isolated and cultured $N$. palea strain showed rapid 
reproduction and high biomass production during the study. The biochemical composition of the strain can be used for biodiesel production and nutritional purposes. Diatoms have been one of the most promising organisms in recent years, especially in nanotechnological applications, in addition to biomass for nutrition. Due to the remarkable characteristics of diatoms, it can be stated that it is possible to design and produce specific frustule morphologies for potential nanotechnology applications. FTIR spectra can provide data on the cellular content of

\section{References}

1. Abdel-Hamid, M.I., El-Refaay, D.A., Abdel-Mogib, M. \& Azab, Y.A. 2013. Studies on biomass and lipid production of seven diatom species with special emphasis on lipid composition of Nitzschia palea (Bacillariophyceae) as reliable biodiesel feedstock. Algological Studies, 143: 65-87.

2. Ammar, S.H. 2016. Cultivation of microalgae Chlorella vulgaris in airlift photobioreactor for biomass production using commercial NPK nutrients. Al-Khwarizmi Engineering Journal, 12(1): 90-99.

3. AOAC (Association of Official Analytical Chemists). 1990. Official Methods of Analysis of the Association of Official Analytical Chemists. Arlington, VA., 771 pp.

4. Belegratis, M.R., Schmidt, V., Nees, D., Stadlober, B. \& Hartmann, P. 2014. Diatom-inspired templates for 3D replication: natural diatoms versus laser written artificial diatoms. Bioinspiration \& Biomimetics, 9: 1-11.

5. Binea, H.K., Kassim, T.I. \& Binea, A.K. 2009. Antibacterial activity of diatom Nitzschia palea (Kuetz.) W.SM. extract. Iraqi Journal of Biotechnology, 8(2): 562-566.

6. Bozarth, A., Maier, U.G. \& Zauner, S. 2009. Diatoms in biotechnology: modern tools and applications. Applied Microbiology and Biotechnology, 82: 195-201.

7. CCAP, Culture Collection of Algae and Protozoa, Scottish Marine Institute, (https://www.ccap.ac.uk/), (Date accessed: 18 November 2018).

8. Cirik, S. \& Gökpınar, Ş. 1993. Plankton Bilgisi ve Kültürü. Ege Üniversitesi Su Ürünleri Fakültesi Yayınları, İzmir, $269 \mathrm{~s}$.

9. Chaumont D. 1993. Biotechnology of algal biomass production: a review of systems for outdoor mass culture. Journal of Applied Phycology, 5: 593-604.

10. Dean, A.P., Sigee, D.C., Estrada, B. \& Pittman, J.K. 2010. Using FTIR spectroscopy for rapid determination of lipid accumulation in response to nitrogen limitation in freshwater microalgae. Bioresource Technology, 101: 4499-4507.

11. Dębowski, M., Zieliński, M., Krzemieniewski, M., Dudek, M. \& Grala, A. 2012. Microalgae cultivation methods. Polish Journal of Natural Sciences, 27(2): 151-164.

12. Duygu, D., Udoh, A.U., Özer Baykal, T., Akbulut, A., Erkaya Açıkgöz, I., Yıldız, K. \& Deniz, G. 2012. Fourier Transform Infrared (FTIR) spectroscopy for identification of Chlorella vulgaris Beijerinck 1890 and Scenedesmus obliquus (Turpin) Kützing 1833. African Journal of Biotechnology, 11(16): 3817-3824. macromolecular pools, using small amounts of cell material. By applying the information contained in the FTIR spectrum, the locations of specific biomolecules within the cell for algal species can be identified and analyzed. Due to this feature, FTIR has recently become a technique which have been applied by researchers to clarify the molecular structure of biological materials. As a result, researches on the use of diatoms' bioactive compounds in different areas of the industry especially biodiesel research need to be diversified.

13. Fimbres-Olivarría, D., López-Elías, J.A., MartínezCórdova, L.R., Carvajal-Millán, E., Enríquez-Ocaña, F., Valdéz-Holguín, E. \& Miranda-Baeza, A. 2015. Growth and biochemical composition of Navicula sp. cultivated at two light intensities and three wavelengths. The Israeli Journal of Aquaculture, 1-7.

14. Gonçalves, A., Pires, J. \& Simões, M. 2013. Lipid production of Chlorella vulgaris and Pseudokirchneriella subcapitata. International Journal of Energy and Environmental Engineering, 4: 1-6.

15. Gürgün, V. \& Halkman K. 1990. Mikrobiyolojide Sayım Yöntemleri. Gıda Teknolojisi Derneği Yayınları, Ankara, $106 \mathrm{~s}$.

16. Guillard, R.R. \& Ryther, J.H. 1962. Studies on marine planktonic diatoms. I. Cyclotella nana Hustedt and Detonula confervacaea (Cleve) Gran. Canadian Journal of Microbiology, 8: 229-239.

17. Guillard, R.R.L. \& Lorenzen, C.J. 1972. Yellow-green algae with chlorophyllide c. Journal of Phycology, 8: 1014.

18. Guiry, M.D. \& Guiry, G.M. 2018. AlgaeBase. (http://www.algaebase.org), (Date accessed: 26 November 2018).

19. Hu, Q., Sommerfeld, M., Jarvis, E., Ghirardi, M., Posewitz, M., Seibert, M. \& Darzins, A. 2008. Microalgal triacylglycerols as feedstocks for biofuel production: perspectives and advances. Plant Journal, 54: 621-639.

20. Imamoglu, E., Dalay, M. C. \& Sukan, F.V. 2009. Influence of different stress media and high light intensities on accumulation of astaxanthin in green alga Haematococcus pluvialis. New Biotechnology, 26: 199-204.

21. Krammer, K. \& Lange-Bertalot, H. 1999. Süßwasserflora von Mitteleuropa, Bacillariophyceae, Band 2/2, 2. Teil: Bacillariaceae, Epithemiaceae, Surirellaceae. Gustav Fischer Verlag, Stuttgart, 584 pp.

22. Kumar, V., Kashyap, M., Gautam, S., Shukla, P., Joshi, K.B. \& Vinayak, V. 2018. Fast Fourier Infrared spectroscopy to characterize the biochemical composition in diatoms. Journal of Bioscience, 43(4): 717-729.

23. Lakshmi, K.V., Jeyanthi, S., Santhanam, P., Devi, A.S. \& Balamurugan, A. 2014. Study of self-assembled nanostructure and biomolecules of diatom Nitzschia sp. using electron microscopy and raman spectroscopy. Bionano Frontier, 2: 197-202. 
24. Li, Q., Du, W. \& Liu, D. 2008. Perspectives of microbial oils for biodiesel production. Applied Microbiology and Biotechnology, 80: 749-756.

25. Li, H.Y., Lu, Y., Zheng, J.W., Yang, W.D. \& Liu, J.S. 2014. Biochemical and genetic engineering of diatoms for polyunsaturated fatty acid biosynthesis. Marine Drugs, 12: 153-166.

26. Lourduraj, J.J. \& Abraham, D.R. 2016. Screening of microalgae based on biomass and lipid production at indoor and outdoor cultivation condition. International Journal of Pure \& Applied Bioscience, 4(6): 107-113.

27. Losic, D., Mitchell, J.G. \& Voelcker, N.H. 2009. Diatomaceous lessons in nanotechnology and advanced materials. Advanced Materials, 21: 2947-2958.

28. Markou, G. \& Nerantzis, E. 2013. Microalgae for highvalue compounds and biofuels production: a review with focus on cultivation under stress conditions. Biotechnology Advances, 8: 1532-1542.

29. Michelle, A., Everroad, R.C. \& Wingard, L.M. 2005. Measuring Growth Rates in Algal Culturing Techniques. pp. 269-286 In: Andersen, R.A. (ed). Algal Culturing Techniques. Elsevier Academic Press, London, 589 pp.

30. Minhas, A.K., Hodgson, P., Barrow, C.J. \& Adholeya, A. 2016. A review on the assessment of stress conditions for simultaneous production of microalgal lipids and carotenoids. Frontiers of Microbiology, 7: 1-19.

31. Murdock, J.N. \& Wetzel, D.L. 2009. FT-IR microspectroscopy enhances biological and ecological analysis of algae. Applied Spectroscopy Reviews, 44: 335361.

32. Nichols, H.W. 1973. Growth media-freshwater. Pp. 19-25. In: Stein, J.R. (ed). Handbook of Phycological Methods: Culture Methods and Growth Measurements. Cambridge University Press, New York, 472 pp.

33. Perumal, P., Prasath, B.B., Santhanam, P., Ananth, S., Shenbaga Devi, A. \& Kumar, D. S. 2012. Isolation and culture of microalgae. Workshop on Advances in Aquaculture Technology, 166-181.

34. Rodolfi, L., Zittelli, C., Bassi, G., Padovani, N., Biondi, G. \& Tredici, M.R. 2009. Microalgae for oil: strain selection, induction of lipid synthesis and outdoormass cultivation in a low-costphotobioreactor. Biotechnology and Bioengineering, 102: 100-112.
35. Rodríguez-Núñez, K. \& Toledo-Agüero, P. 2017. Fatty acid profile and nutritional composition of two tropical diatoms from the Costa Rican Pacific Coast. Grasas Aceites, 68(3): 1-8.

36. Supriya, G., Asulabha, K.S. \& Ramachandra, T.V. 2012. Use of Raman microspectroscopy to detect changes in lipid pools of microalgae, 1-8. LAKE 2012: National Conference on Conservation and Management of Wetland Ecosystems, 6-9 November, Kottayam-India.

37. Swann, G.E. \& Patwardhan, S. 2011. Application of Fourier Transform Infrared Spectroscopy (FTIR) for assessing biogenic silica sample purity in geochemical analyses and palaeoenvironmental research. Climate of the Past, 7: 65-74.

38. UTEX, Culture Collection of Algae at the University of Texas at Austin. (http://web.biosci.utexas.edu/utex/Media\%20PDF/allen\% 20medium.pdf), (Date accessed: 23 November 2018).

39. Van den Hoek, C., Mann, D. \& Jahns, H.M. 1995. Algae: an introduction to Phycology. Cambridge University, Cambridge, $623 \mathrm{pp}$.

40. Vardy, S. \& Uwins, P. 2002. Fourier transform infrared microspectroscopy as a tool to differentiate Nitzschia closterium and Nitzschia longissima. Applied Spectroscopy, 56: 1545-1548.

41. Vitug, L.V.D. \& Baldia, S.F. 2014. Enhancement of some culture conditions for optimizing growth and lipid production in the diatom Nitzschia palea. Acta Manilana, 62: $25-34$

42. Wen, Z.Y., \& Chen, F. 2001. A perfusion- cell bleeding culture strategy for enhancing the productivity of eicosapentaenoic acid by Nitzschia laevis. Applied Microbiology and Biotechnology, 57: 316-322.

43. Wong, Y.K., Ho, Y.H., Ho, K.C., Leung, H.M. \& Yung, K.K.L. 2017. Maximization of cell growth and lipid production of freshwater microalga Chlorella vulgaris by enrichment technique for biodiesel production. Environmental Science and Pollution Research, 24: 90899101.

44. Yu, E.T., Zendejas, F.J., Lane, P.D., Gaucher, S., Simmons, B.A. \& Lane, T.W. 2009. Triacylglycerol accumulation and profiling in the model diatoms Thalassiosira pseudonana and Phaeodactylum tricornutum (Bacillariophyceae) during starvation. Journal of Applied Phycology, 21: 669681 . 